\title{
ANALISIS PEMBIAYAAN MURABAHAH PADA BANK MANDIRI SYARIAH KOTA SAMARINDA
}

\author{
Sri Wahyuni \\ Fakultas Ekonomi Universitas Mulawarman Samarinda \\ E-mail:wahyuni_mumtaz@yahoo.co.id
}

\begin{abstract}
This study aims to analyze about Murabahah financing at Mandiri syariah Bank in Samarinda city. Independent variables used in this study are inflation, the net operational margin, total assets and variables that reflect the type of Islamic bank financing policy. The dependent variable used in this study is the ratio of Islamic banks or financing problems in terms of so-called Non-Performing Financing (NPF). One of the results in this study was about Murabahah receivable for profit Loss sharing financing gave the most dominant effect toward Non Performing Finance Gross at Islamic Bank.
\end{abstract}

Keywords: Ratio, Murabahah Receivables, Variables, Islamic Banking.

\begin{abstract}
Abstrak
Penelitian ini bertujuan untuk menganalisis pembiayaan murabahah pada Bank Mandiri Syariah Kota Samarinda. Variabel-variabel bebas yang digunakan dalam penelitian ini adalah inflasi, net operational margin, total aset dan variabel yang mencerminkan jenis kebijakan pembiayaan bank syariah. Variabel terikat yang digunakan dalam penelitian ini adalah rasio pembiayaan bermasalah bank syariah atau dalam terminologi biasa disebut Non Performing Financing (NPF). Salah satu hasil penelitian ini yaitu Piutang Murabahah terhadap Pembiayaan Profit Loss Sharing memberikan pengaruh paling dominan terhadap Non Performing Finance Gross Bank Syariah.
\end{abstract}

Kata Kunci: Rasio, Piutang Murabahah, Variabel, Bank Syariah

Sistem perbankan konvensional selama ini menerapkan konsep bunga bank yang bagi sementara kalangan dianggap sebagai riba yang haram hukumnya dalam syariat Islam. Hal ini menempatkan kalangan umat Islam ke dalam posisi sulit di mana mereka menginginkan transaksi yang bebas riba di satu sisi, sementara di sisi yang lain tidak bisa lepas dariaktivitas perbankan konvensional yang memberlakukan konsep bunga tersebut.
Perbankan Syariah yang memperkenalkan konsep kemitraan dengan sistem bagi hasil merupakan jalan keluar yang bisa ditempuh. Wacana perbankan syariah ini memberikan angin segar yang disambut masyarakat dengan animo tinggi. Wujud konkrit dari animo masyarakat ini dapat dilihat dari semakin menjamurnya lembaga keuangan (bank maupun non bank) berbasis syariah di Indonesia dan antusiasme masyarakat dalammenggunakan 
Ekonomika-Bisnis Vol. 6 No.1 Bulan Januari Tahun 2015. Hal 47-54

jasa lembaga-lembaga keuangan syariah tersebut (Imama, 2008: 309).

Seiring dengan perkembangan peraturan perundang-undangan yang lebih baru mengenai perbankan syariah, maka dunia perbankan syariah di Indonesia semakin menemukan pondasi dan bentuknya. Berdasarkan laporan dari Bank Indonesia, pertumbuhan Perbankan Syariah terus bertumbuh dengan sangat menggembirakan, dan sampai bulan Oktober 2012, total asetnya mencapai Rp.174,09 triliun, dengan perincian pembiayaan mencapai Rp.135,58 triliun (40,06\%) dan penghimpunan dana mencapai Rp.134,45 triliun $(32,06 \%)$.

Sebagai akibat dariskema bagi hasil dan resiko (profit and loss sharing) tersebut, ada kecenderungan bank-bank syariah lebih berhati-hati dalam menyalurkan pembiayaan kepada dunia usaha. Perbankan syariah cenderung memilih jenis pembiayaan dengan resiko rendah seperti murabahah dan sedikit berhati-hati pada jenis pembiayaan beresiko tinggi sepertimudharabah dan musyarakah. Hal ini dapat dilihat pada laporan Bank Indonesia di atas, di mana pembiayaan murabahah mencapai 59,71\% sementara musyarakah hanya sekitar 18,59\% dan mudharabah sebesar $8,44 \%$.

Padahal, seharusnya bank sebagai lembaga keuangan yang berfungsi sebagai mediator antara pihak yang kelebihan dana dengan pihak yang membutuhkan dana bisa menyalurkan dana tersebut secara merata, termasuk kepada bidang-bidang pembiayaan yang beresiko tinggi dengan tetap memperhatikan dan tidak meninggalkan prinsip kehati-hatian bank. Konsep bagi hasil dan resiko (profit and loss sharing) harus lebih dipahami dan dijiwai baik oleh pihak bank maupun pihak nasabah sehingga kedua belah pihak dapat menjalankan usahanya tanpa ke- takutan yang berlebihan sehingga produk mudharabah dan musyarakah yang lebih sesuai dengan prinsip bagi hasil dan resiko akan menjadi produk bank syariah yang diutamakan.

Berdasarkan pada latar belakang permasalahan di atas, maka permasalahan dalam penelitian ini dapat dirumuskan sebagai berikut: (1) Bagaimana pengaruh secara simultan dari variabel bebas Net Operational Margin, Rasio Piutang Murabahah terhadap Pembiayaan Profit Loss Sharing, Rasio Pendapatan dari Sistem Bagi Hasil terhadap Pendapatan dari Penyaluran Dana, Inflasi, dan TotalAset terhadap Non Performing Finance Gross Bank Syariah? (2) Bagaimana pengaruh secara parsial dari variabel bebas Net Operational Margin, Rasio Piutang Murabahah terhadap Pembiayaan Profit Loss Sharing, Rasio Pendapatan dari Sistem Bagi Hasil terhadap Pendapatan dari Penyaluran Dana, Inflasi, dan Total Aset terhadap Non Performing Finance Gross Bank Syariah? (3) Faktor manakan yang memberikan pengaruh paling dominan terhadapNon Performing Finance Gross Bank Syariah?

Adapun tujuan dari penelitian sesuai dengan rumusan permasalahan diatas, yaitu: (1) Mengetahui pengaruh secara simultan dari variabel bebas Net Operational Margin, Rasio Piutang Murabahah terhadap Pembiayaan Profit Loss Sharing, Rasio Pendapatan dari Sistem Bagi Hasil terhadap Pendapatan dari Penyaluran Dana, Inflasi, dan Total Aset terhadap Non Performing Finance Gross Bank Syariah. (2) Untuk mengetahui pengaruh secara parsial dari variabel bebas Net Operational Margin, Rasio Piutang Murabahah terhadap Pembiayaan Profit Loss Sharing, Rasio Pendapatan dari Sistem Bagi Hasil terhadap Pendapatan dari Penyaluran Dana, Inflasi, dan Total Aset terhadap Non Performing Finance Gross Bank Syariah. (3) 
Analisis Pembiayaan Murabahah pada Bank Mandiri Syariah.... (Sri Wahyuni)

Untuk mengetahui faktor yang memberikan pengaruh paling dominan terhadapNon Performing Finance Gross Bank Syariah.

\section{Metode Penelitian}

Variabel-variabel bebas yang digunakan dalampenelitian ini adalah inflasi, netoperational margin, total aset dan variabel yang mencerminkan jenis kebijakan pembiayaan bank syariah. Modeldiestimasi dengan menggunakan pendekatan Error Correction Model (ECM) untuk melihat ada tidaknya keseimbangan antara jangka pendek dengan jangka panjang dan menginterpretasikan analisis pengaruh variabeldalam jangka pendek. Sedangkan analisis untukhubungan jangkapanjang ditemukan dari pendekatan hasil regresi Ordinary Least Square (OLS). Sampel time series yang digunakan dalam penelitian ini adalah Bank Syariah Mandiri Cabang Kota Samarinda.

Variabel terikat yang digunakan dalam penelitian ini adalah rasio pembiayaan bermasalah bank syariah atau dalam terminologibiasa disebut Non Performing Financing (NPF).

Seperti yang telah dikemukakan pada bab terdahulu, model yang digunakan dalam penelitian ini adalah model regresi berganda (multiple regression). Menurut Pratisto (2004: 112), mengemukakan bahwa analisis regresi bertujuan untuk mengetahui pengaruh variabel bebas $(\mathrm{X})$ terhadap variabel terikat $(\mathrm{Y})$. Persamaan yang diperoleh dari perhitungan regresi harus diuji secara statistik nilai koefisien regresinya. Hubngan fungsional antara variabel independent dan dependent dapat diformulasikan melaluipersamaan regresi yang dimaksudkan untuk memprediksikan nilai variabel tidak bebas.

Untuk menguji hipotesis, maka menggunakan uji $\mathrm{R}$, uji $\mathrm{R}^{2}$, dan ujit, untuk menge- tahui pengaruh antara variabel bebas dengan variabel terikatnya.

Penganalisaan koefisien korelasi (R) atau dengan istilah lain yang berarti koefisien dan pengujian korelasi. Penjelasan tentang nilai korelasi + 1 atau -1 agar lebih mudah dijelaskan, maka menurut pendapat dari Sarwono (2007:183), dikemukakan bahwa ukuran untuk menafsirkan dari korelasi adalah sebagai berikut:
1) $0-0,25$
: Korelasi sangat lemah
2) $>0,25-0,5$ :Korelasi cukup
3) $>0,5-0,75$ : Korelasi kuat
4) $<0,75-1 \quad$ :Korelasi sangat
kuat

Untuk selanjutnya akan diadakan pengujian hipotesis untuk mengetahui koefisien populasi yang tidak diketahui berdasarkan estimasi koefisien korelasi sampel.

Analisis terhadap tingkat pengaruh antara varaibel atau koefisien kolarasi $\left(\mathrm{R}^{2}\right)$, dilakukan dengan untuk mengetahui tingkat pengaruh yang ditimbulkan oleh variabel independent terhadap variabel dependent secara simultan di dalam penelitian ini.

Pengujian adalahuntuk mengetahui apakah koefisien regresi variabel bebas secara bersama-sama berpengaruh atau tidak terhadap variabel tidak bebas. Adapun kriteria pengujian, sebagai (1) Merumuskan Hipotesis Statistik H: $b_{1}=b_{2}=b_{3}=0$, artinya tidak terdapat pengaruh yang berarti secara bersama-sama antara variabel Independent $(\mathrm{X})$ terhadap dependent (Y). H: $b_{1}{ }^{~}{ }^{\prime} b_{2}{ }{ }^{\prime \prime} b_{3}{ }^{\prime \prime} 0$, artinya terdapat pengaruh yang berarti secara bersama-sama antara variabel variabel Independent $(\mathrm{X})$ terhadap dependent $(\mathrm{Y})$. (1) Level of significant (á) $=0,05$ dengan $\mathrm{df}=(\mathrm{n}-\mathrm{k}-1)$, di mana menentukan nilai $\mathrm{F}_{\text {tabel }}$ digunakan signifikansi $5 \%$ dengan derajat kebebasan (degree of freedom) $\mathrm{df}=(\mathrm{n}-\mathrm{k})$ 
dan (k-1), di mana n adalah sebagai jumlah variabel termasuk intersep dan $\mathrm{k}$ adalah variabel dependent. (2) Kriteria penerimaan dan penolakan $\mathrm{H}_{0}$ dan $\mathrm{H}_{\mathrm{a}}$ adalah sebagai berikut: - Jika $\mathrm{F}_{\text {Hitung }}>\mathrm{F}_{\text {Tabel }}$ maka $\mathrm{H}_{0}$ ditolak dan $\mathrm{H}_{\mathrm{a}}$ diterima.

- Jika $\mathrm{F}_{\text {Hitung }}<\mathrm{F}_{\text {Tabel }}$ maka $\mathrm{H}_{0}$ diterima dan $\mathrm{H}_{\mathrm{a}}$ ditolak.

\section{Hasil Penelitian dan Pembahasan}

Dari hasil analisis regresi linear berganda dengan menggunakan SPSS akan dibuktikan hipotesis keempat yang telah ditetapkan diBab II. Dari hasil perhitungan dengan SPSS diperoleh persamaan linear sebagai berikut:

$\mathrm{Y}=27,350+1,102 \mathrm{NOM}+1,508 \mathrm{RF}+$ $0,856 \mathrm{RR}+0,911$ Inflasi + 0,753 Size

Di mana:

NPFG : Non Performing Finance Gross Bank Syariah

NOM : Net Operational Margin Bank Syariah

RF : Rasio Piutang Murabahah terhadap Pembiayaan Profit Loss Sharing

RR : Rasio Pendapatan dari Sistem Bagi Hasil terhadap Pendapatan dari Penyaluran Dana

INF : Inflasi

SIZE : TotalAset

Uji F dilakukan untuk mengetahui apakah hubungan antara dua variabel bersifat linear. Adapun kriteria yang digunakan untuk melihat linearitas antara variabel bebas terhadap variabel terikat dengan cara melihat nilai p-value (probabilitas) pada TabelANOVA. Dari hasil perhitungan dengan SPSS terlihat bahwa nilai $F$ adalah sebesar 25,315 $(\mathrm{p}$-value $=0)$. Nilai $\mathrm{p}$-value $=0(\mathrm{nol})$ tersebut lebih kecil dari nilai alpha $(0,05)$. Karena nilai p-value < alpha maka dapat disimpulkan bahwa ada pengaruh secara bersama-sama antara variabel bebas Net Operational Margin, Rasio Piutang Murabahah terhadap Pembiayaan Profit Loss Sharing, Rasio Pendapatan dari Sistem Bagi Hasil terhadap Pendapatan dari Penyaluran Dana, Inflasi, dan Total Aset terhadap Non Performing Finance Gross Bank Syariah.

Uji Statistik t dilakukan untuk mengetahui apakah ada pengaruh variabelNet Operational Margin, Rasio Piutang Murabahah terhadap Pembiayaan Profit Loss Sharing, Rasio Pendapatan dari Sistem Bagi Hasil terhadap Pendapatan dari Penyaluran Dana, Inflasi, dan Total Aset terhadap Non Performing Finance Gross Bank Syariah. Adapun kriteria yang digunakan untuk melihat pengaruh variabel Net Operational Margin, Rasio Piutang Murabahah terhadap Pembiayaan Profit Loss Sharing, Rasio Pendapatan dari Sistem Bagi Hasil terhadap Pendapatan dari Penyaluran Dana, Inflasi, dan TotalAset terhadap Non Performing Finance Gross Bank Syariah adalah dengan cara melihat nilai p-value (probabilitas) pada Tabel Cofficients. Dari hasil perhitungan dengan SPSS terlihat bahwa nilai t adalah sebagaimana tercantum pada tabel 1 .

Menurut Ghozali (2005:85), karena nilai p-value < alpha maka dapat disimpulkan bahwa variabel variabel bebas Net Operational Margin, Rasio Piutang Murabahah terhadap Pembiayaan Profit Loss Sharing, Rasio Pendapatan dari Sistem Bagi Hasil terhadap Pendapatan dari Penyaluran Dana, Inflasi, dan Total Aset berpengaruh secara parsial terhadap Non Performing Finance Gross Bank Syariah. Dengan demikian dapat disimpulkan bahwa Ha diterima. Ini me- 
Analisis Pembiayaan Murabahah pada Bank Mandiri Syariah.... (Sri Wahyuni)

nunjukkan bahwa Hipotesis pertama sampai dengan hipotesis kelima telah terbukti.

Koefisien determinasi atau nilai adjusted R2 adalah pengukuran dari nilai koefisien korelasi (R). NilaiAdjusted R2 yang tersaji dalam Tabel Model Summary menunjukkan nilai 0,466 atau $46,6 \%$. Hal tersebut bisa diartikan bahwa 46,6\% Non Performing Finance Gross Bank Syariah dapat jelaskan oleh variabel Net Operational Margin, Rasio Piutang Murabahah terhadap Pembiayaan Profit Loss Sharing, Rasio Pendapatan dari Sistem Bagi Hasil terhadap Pendapatan dari Penyaluran Dana, Inflasi, dan Total Aset sedangkan sisanya sebesar 55,4\% dijelaskan oleh variabel-variabel lain di luar variabel $\mathrm{Net}$ Operational Margin, Rasio Piutang Murabahah terhadap Pembiayaan Profit Loss Sharing, Rasio Pendapatan dari Sistem Bagi Hasil terhadap Pendapatan dari Penyaluran Dana, Inflasi, dan Total Aset. Nilai R2 dalam penelitian ini termasuk dalam kategori sedang, sehingga bisa dikatakan bahwa variabel Net Operational Margin, Rasio Piutang Murabahah terhadap Pembiayaan Profit Loss Sharing, Rasio Pendapatan dari Sistem Bagi Hasil terhadap Pendapatan dari Penyaluran Dana, Inflasi, dan TotalAset berpengaruh terhadap variabel Non Performing Finance Gross Bank Syariah.

Menurut Ghozali (2004) ada dua hal yang perlu mendapat perhatian jika menggunakan standardized beta, yaitu: (1) koefisien beta digunakan untuk melihat pentingnya masing-masing variabel independen secara relatif antar variabel independen, (2) nilai koefisien beta hanya dapat diinterpretasikan dalam konteks variabel lain dalam persamaan regresi.

Dari hasil perhitungan dengan menggunakan analisis regresi linear berganda terlihat bahwa variabelRF memiliki nilai koefisien beta yang terbesar $(0,245)$ dibandingkan dengan variabel-variabel bebas yang lain. Dengan demikian variabel RF merupakan variabel yang paling berpengaruh dalam model penelitian ini.

\section{Penutup}

Berdasarkan hasil analisis dan pembahasan maka dapat ditarik kesimpulan sebagai berikut: (1) Secara simultan dari variabel

Tabel 1. Hasil Perhitungan t hitung dan p-value dengan persamaan regresi linear berganda

\begin{tabular}{lccc}
\hline \multicolumn{1}{c}{ Variabel } & $\mathbf{t}_{\text {hitung }}$ & p value & Keterangan \\
\hline Net Operational Margin & 3,192 & 0,002 & Berpengaruh \\
$\begin{array}{l}\text { Rasio Piutang Murabahah terhadap } \\
\text { Pembiayaan Profit Loss Sharing }\end{array}$ & 3,636 & 0,000 & Berpengaruh \\
$\begin{array}{l}\text { Rasio Pendapatan dari Sistem Bagi Hasil } \\
\text { terhadap Pendapatan dari Penyaluran Dana }\end{array}$ & 1,994 & 0,048 & Berpengaruh \\
$\begin{array}{l}\text { Inflasi } \\
\text { Total Aset }\end{array}$ & 2,527 & 0,028 & Berpengaruh \\
& 2,112 & 0,036 & Berpengaruh \\
\hline
\end{tabular}

Tabel 2. Hasil Analisis Regresi

\begin{tabular}{lcrrrr}
\hline Model & R & R Square & $\begin{array}{c}\text { Adjusted R } \\
\text { Square }\end{array}$ & $\begin{array}{c}\text { Std. Error of the } \\
\text { Estimate }\end{array}$ & $\begin{array}{c}\text { Durbin } \\
\text { Watson }\end{array}$ \\
\hline & $.693^{\mathrm{a}}$ & .480 & .466 & 6.984 & 2.160 \\
\hline
\end{tabular}

Predictors: (Constant), Size, RF, NOM, Inflasi, RR 
Ekonomika-Bisnis Vol. 6 No.1 Bulan Januari Tahun 2015. Hal 47-54

bebas Net Operational Margin, Rasio Piutang Murabahah terhadap Pembiayaan Profit Loss Sharing, Rasio Pendapatan dari Sistem Bagi Hasil terhadap Pendapatan dariPenyaluran Dana, Inflasi, dan Total Aset terhadap Non Performing Finance Gross Bank Syariah. (2) Secara parsial dari variabel bebas Net Operational Margin, Rasio Piutang Murabahah berpengaruh terhadap Pembiayaan Profit Loss Sharing, Rasio Pendapatan dari Sistem Bagi Hasil terhadap Pendapatan dari Penyaluran Dana, Inflasi, dan Total Aset terhadap Non Performing Finance Gross Bank Syariah. (3) Piutang Murabahah terhadap Pembiayaan Profit Loss Sharing memberikan pengaruh paling dominan terhadap Non Performing Finance Gross Bank Syariah.

\section{DAFTAR PUSTAKA}

Alamsyah, Halim. 2012. Perkembangan dan Prospek Perbankan Syariah Indonesia: Tantangan dalam Menyongsong MEA 2015. Ceramah Ilmiah Ikatan AhliEkonomi Islam, Milad ke8, 13 April 2012.

Andini, Pratiwi Puspitho. 2013. Manajemen Risiko dalam Perbankan Syari'ah di Indonesia.http://repository.unej.ac.id/ bitstream/handle/123456789/1421/ Jurnal\%20Pratiwi.pdf?sequence=1,diakses tanggal 5 Februari 2014.

Anto, MB. Hendri., dan Setyowati, Desti. 2009. The Indication of Moral Hazard in Financing: A Comparative Study Between Islamic Bank and Conventional bank In Indonesia 2003: 1-2007: 9. Kencana. Jakarta.

Antonio, Muhammad Syafi'i. 2007. Bank Syariah: Dari teori ke Praktik. Gema Insani. Jakarta.
Arikunto, Suharsimi. 2006. Prosedur Penelitian. Rineka Cipta. Jakarta.

Ariyanto, Taufik. 2011. Faktor Penentu Net Interest Margin Perbankan Indonesia. Finance and Banking Journal. Vol. 13, No. 1, Halaman 34-46.

Ascarya, dkk. 2009. Analisis Efisiensi Perbankan Konvensional dan Perbankan Syariah di Indonesia dengan Data Envelopment Analysis. Kencana. Jakarta.

Asmuni. 2004. Aplikasi Musyarakah dalam Perbankan Islam. Al-Mawarid, Ed. XI, hal 20-45

Christianti, Ari. 2011. Diversifikasi Kredit terhadap Profitabilitas dan Probabilitas Kegagalan Bank. Jurnal Keuangan dan Perbankan. Vol. 15, No. 3, Halaman 428-436.

Desiana, dkk., 2013. Analisa Perbandingan Kinerja Keuangan antara PT. Bank Muamalat Indonesia, Tbk dan PT. Bank Syariah Mandiri dengan Menggunakan Rasio Camel Sebelum dan Sesudah Krisis Ekonomi Global Tahun 2008. http:/ /pta.trunojoyo.ac.id/uploads/journals / 090221100029 / 090221100029.pdf, diakses tanggal 07 Desember 2013.

Daymon, Christine \& Immy Holloway. 2002. Metode Riset Kualitatif. Bentang. Yogyakarta.

Dyahrini, Wien dan Rachman, Ibnu. 2012. Pengaruh Inflasi terhadap Perekonomian di Kotamadya dan Kabupaten Bandung Berdasarkan Persepsi Produsen dan Konsumen. http://repository.widyatama.ac.id/xmlui/ 
Analisis Pembiayaan Murabahah pada Bank Mandiri Syariah.... (Sri Wahyuni)

handle/123456789/1922, diakses tanggal 09 Desember 2013.

Fatahullah. 2008. Implementasi Prinsip Bagi Hasil dan Risiko di Perbankan Syariah. Jurnal Tesis. Magister Ilmu Hukum Universitas Diponegoro Semarang, http://ejournal.undip.ac.id/

Hafidhuddin, Didin. 2003. Islam Aplikatif. Gema Insani Press. Jakarta.

Hatta. 2008. Telaah Singkat Pengendalian Inflasi dalam Perspektif Kebijakan Moneter Islam. http://www.jurnalekonomi.org/2008/06/16/telaahsingkat-pengendalian-inflasi-dalamperspektif-kebijakan-moneter-islam/, diakses tanggal 07 Desember 2013

Imama, Lely Shofa. 2008. Ekonomi Islam: Rasional dan Relevan. La Riba, Vol II, No. 2. Hal. 309-317.

Ismal, Rifki. 2013. Islamic Banking in Indonesia: New Perspektives on Monetary and Financial Issues. John Wiley Inc. Singapura.

Ismail Yusanto. Analisis Keuangan Bank Muamalat Indonesia Pada Periode Krisis Ekonomi Tahun 1998 - 1999. Program Pascasarjana Sekolah Tinggi Ekonomi IPWI Jakarta, 2000.

Jarjawi, A.Y.A. 2006. Indahnya Syariat Islam. Gema Insani Press. Jakarta.

Kartajaya, Hermawan dan Sula, Muhammad Syakir. 2006. Syariah Marketing. Mizan. Bandung.

Laksmana, Yusak. 2009. Cara Mudah Mendapatkan Pembiayaan di Bank Syariah. Elex Media Komputindo. Jakarta.
Latumaerissa, Julius R. 2011. Bank dan Lembaga Keuangan Lain. Salemba Empat. Jakarta.

Lubis, Irsyad. 2010. Bank dan Lembaga Keuangan. USU Press. Medan.

Margaretha, Farahdan Setiyaningrum, Diana. 2011. Pengaruh Risiko, Kualitas Manajemen, Ukuran dan Likuiditas Bank terhadap Capital Adequacy Ratio Bank-Bank yang Terdaftar diBursa Efek Indonesia. Jurnal Akuntansi dan Keuangan. Vol. 13, No. 1, Halaman 47-56.

Mubruroh. 2004. Manfaat dan Pengaruh Rasio Keuangan Dalam Analisis Kinerja Keuangan Perbankan. Jurnal Akuntansi dan Keuangan. Vol8. No. 1 Juni.

Pawito. 2007. Penelitian Komunikasi Kualitatif. LkiS. Yogyakarta.

Prastika, Nurhikmah Esti. 2010. Analisis Kinerja Keuangan Bank Mega Syariah Periode 2005-2010 (dengan Pendekatan PBI No. 9/I/PBI/2007). Jurnal Majalah Neraca. Vol. 6, No. 2, Halaman 1-22.

Sula, Muhammad Syakir. 2004. Asuransi Syariah: Life and General: Konsep dan Sistem Operasional. Gema Insani Press. Jakarta.

Wiroso. 2005. Penghimpunan Dada dan Distribusi hasil Usaha Bank Syariah. Grasindo. Jakarta.

Wiyono S. 2008. Cara Mudah Memahami Akutansi Perbangkan Syariah. Berdasar PSAK dan PAPSI. Grasindo. Jakarta. 
